ORIGINAL ARTICLE

\title{
REVIEW ARTICLE: AMEBIASIS MOLECULAR PATHOGENESIS DEVELOPMENT
}

\author{
Nurlina Muliani ${ }^{1 *}$, Hotimah Masdan Salim² \\ ${ }^{1}$ Master of Clinical Pharmacy at the University of Surabaya \\ ${ }^{2}$ Faculty of Medicine, University of Nahdlatul Ulama Surabaya \\ *Correspondent author: nurlinamuliani95@gmail.com
}

\section{ARTICLE INFO \\ Article history: \\ Submission: July 262019 \\ Received in revised form \\ August 2019 \\ Accepted: August 212019}

\section{Keywords:}

Pathogenesis, Molecular,

Amoeba, Amebiasis,

Entamoeba histolytica

\begin{abstract}
Amebiasis is one of the gastrointestinal tract infection disease caused by Entamoeba histolytica, a parasitic protozoan. Amebiasis is the second disease, caused by parasite, that leading cause of death after malaria. Infection occurs through faecaloral route and after ingestion a contaminated food and beverages by human faeces. The pathogenesis of E. histolytica can be classified into 3 processes, i.e: death of host cell, inflammation, and parasitic invasion. The recent years, a molecularly amebiasis pathogenesis has been developed, i.e: adherence, phagocytosis, tropogocytosis of host cell and how the parasites can survive and attack host cells so it can cause an infection in humans. Molecular development is an important thing to be considered in the selection of amebiasis therapy.
\end{abstract}

@ 2019 Medical and Health Science Journal. 10.33086/mhsj.v3i2.1195

\section{INTRODUCTION}

Amebiasis is one of the gastrointestinal tract infections caused by Entamoeba histolytica which is an unicellular and anaerob microorganism ${ }^{(1,2)}$. About $80-90 \%$ of infections have no symptoms and self-limiting ${ }^{(3,4)}$ and $10-20 \%$ can cause severe infections, amebic liver abscess and amebic colitis $^{(4,5)}$. Amebic colitis, the major cause of severe diarrhea at the world and registered in 15 causes of diarrhea at children aged 2 years living in developing countries ${ }^{(4)}$. Diarrhea is the number two cause of death in children under 5 years and kills around 525,000 children every year ${ }^{(6)}$. Based on RISKESDAS (2007), the prevalence of diarrhea in Indonesia is $9.0 \%$ with a range of $4.2-18.9 \%$, the highest prevalence in the Province of Nanggroe Aceh Darussalam and the lowest in the Province of DI Yogyakarta ${ }^{(7)}$.

Progress in molecular methodology increases our knowledge regarding the differences in E. histolytica with other non-pathogenic Entamoeba species such as E. dispar and E.

Correspondence: Nurlina Muliani

@2019 Medical and Health Science Journal. 10.33086/mhsj.v3i2.1195

Available at http://journal2.unusa.ac.id/index.php/MHSJ
Bangladeshi ${ }^{(4)}$. In the last few years the pathogenesis of amebiasis is molecularly developed. Likewise, the mechanism for avoiding immune responses can increase our knowledge regarding amebiasis and can help in the selection of amebiasis therapy.

\section{AMEBIASIS}

\section{Epidemiology}

Amebiasis is found throughout the world with the greatest prevalence in developing countries, mainly in tropical and subtropical regions, specifically Asia, Africa, Indonesia, India, Mexico, South Africa, and South America. Optimal climate conditions in the zone that make protozoan cysts can last for several days in the external environment ${ }^{(1,2,4)}$.

Entamoeba histolytica is the number two cause of death caused by parasites in humans after malaria. Globally, around 50 million people have infections, with greater than 100,000 deaths each year reported due to amebiasis. The source of 
infection is from swallowing water or food contaminated with faeces containing E. histolytica cyst $^{(8)}$. In areas with low socio-economic conditions, there is a decrease in sanitation and an increase in faecal contamination from water supplies $^{(4,8)}$. Relatively better hygiene and sanitation in developed countries has a low incidence of amebiasis, which is $2-11 \%$, whereas in Indonesia it has a quite high range ie $10-18 \%{ }^{(9)}$.

\section{Life cycle}

E. histolytica has a life cycle that can be divided into 2 phase, as an infectious cyst or invasive trophozoite ${ }^{(4)}$. E. histolytica cysts can be discovered in contaminated food or water, after consumption occurs excystation, then trophozoites colonize the large intestine multiplying with binary fission. It can be asymptomatic or cause symptoms such as diarrhea. Trophozoites that attack the intestine produce amoebic colitis with ulceration which causes bloody diarrhea. Trophozoites can spread through the bloodstream and cause abscesses in some organs, which are most often observed or spread to farther places such as the brain and lungs in a hematogenous manner (Figure 1). Within a few weeks after ingestion, symptoms can occur but sometimes can also develop for several years after infection ${ }^{(4,11)}$.

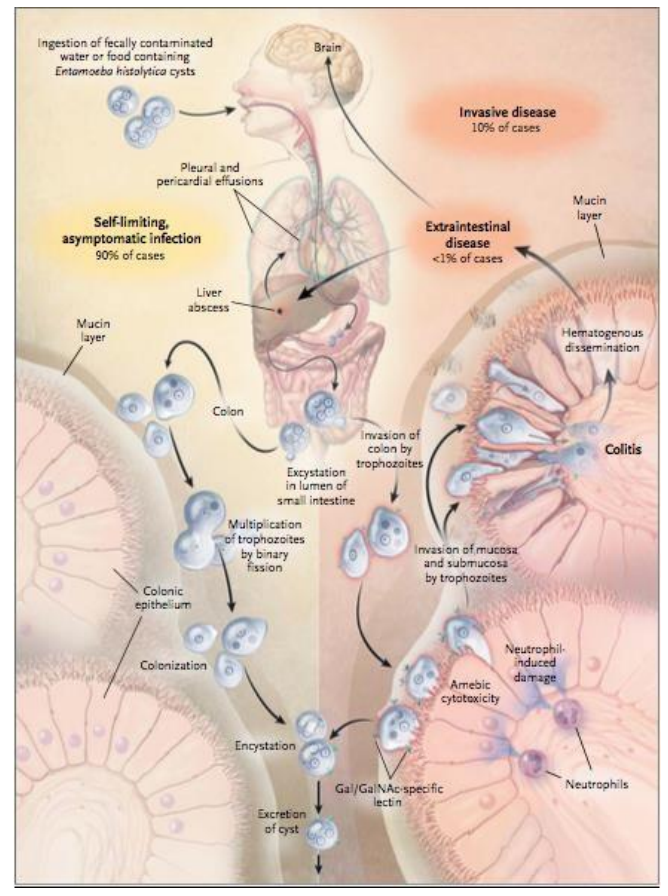

Figure 1. Life Cycle of E. Histolytica ${ }^{(14)}$

\section{MOLECUL SURFACE OF ENTAMOEBA CELL HISTOLYTICA}

\section{Lipophosphopeptidoglycan and Other GPI- Anchored Cell Surface Molecules}

On the trophozoite surface has lipophosphopeptidoglycans

(LPPG), glycosylphosphatidylinositol (GPI) which contains complex carbohydrates and forms a glycocalyx layer. These molecules are the main surface components that interact with target cells, ie human tissue, via terminal sugar molecules ${ }^{(9)}$.

\section{Gal/ Gal NAc Lectin Galactose/ N acetyl D- galactosamine inhibitable (Gal/GalNAc)}

One of the main cell surface molecules associated with adherence to E. histolytica to the basement membrane and epithelial tissue. The Gal/GalNAc lectin consists of Heavy subunits $(\mathrm{Hgl})$, Light subunits (Lgl) and Subunit intermediates (Igl). $\mathrm{HgI}$ and $\mathrm{LgI}$ are connected via disulfide bonds and live on the parasite cell membrane as a $260 \mathrm{kDa}$ heterodimer. $\mathrm{HgI}$ contains carbohydrate recognition domain (CRD) which recognizes d-galactose and N-acetyl-dgalactosamine and host cell glycoconjugate proteins ${ }^{(3,12)}$.

\section{SECRETED MOLECULES INVOLVED IN PATHOGENESIS}

Damage to the extracellular matrix, tissue, and cells is a characteristic pathophysiological of amoeba. Cell contact is the beginning of invasion of E. histolytica. Amoeba also attacks by reducing or damaging tissue by secreting several enzymes capable of digesting tissues or even extracellular matrices $^{(12)}$.

\section{Cysteine Proteases (CP)}

Entamoeba secretes Cysteine Proteases which are the main group of hydrolases. Genome helps identify about 50 genes that encode cysteine peptidase. Only $20 \mathrm{CP}$ genes contained in E. histolytica are secreted, where EhCP1, EhCP2 and EhCP5 constitute $90 \%$ of all existing CP. CP can reduce extracellular matrix proteins (ECM) such as mucin which is the main component of colon 
mucus. CP also attacks the immune system by reducing host antibodies. EhCP5 found on the surface of the amoeba suspected to interfere with mucin barrier of the colon. EhCP5 is also associated with colon epithelial cell integrins and activates the NFkappa $\beta$-mediated inflammatory response in host cells. Research in 2014 showed that EhCPA5 activates matrix metalloproteinase (MMP) by splitting ${ }^{(12,13)}$.

\section{Amoebapores}

Amoebapores is a group of pore-forming peptides that mediate the killing of cells by acting as secreted toxins. Amoebapores has 3 different types (a, b, and c) which structurally and functionally similar to NK-lysin membrane and granulysin permeabilization proteins produced by mammalian $\mathrm{T}$ cells ${ }^{(11,12)}$. All amoebapores induce pore formation in synthetic liposomes. Amoebapores requires $\mathrm{pH} \sim 5.2$ for pore-forming activities needed for activity on the host cell membrane ${ }^{(11)}$.

\section{PATHOGENESIS}

The pathogenesis of E. histolytica can be classified into three, namely: host cell death, inflammation, and parasitic invasion. Trophozoit can kill host cells with several different mechanisms, ie induction of programmed cell death, phagocytosis, and trogocytosis ${ }^{(4)}$.

\section{Programmed Cell Death}

The initial pathogenesis begins with adherence of parasites in the colonic mucous layer through the Gal / GalNAc lectin adhesion molecule (Figure 2).
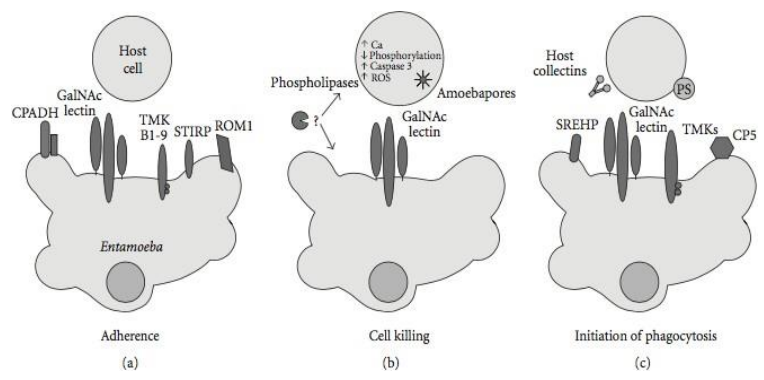

Figure 2. Sequential model of cell killing and phagocytosis by Entamoeba histolytica ${ }^{(3)}$.
Several other molecules involved in the pathogenesis of amebiasis, namely Amoebapores which destroy bacteria in the colon environment. $\mathrm{CP}$ is considered an important parasitic weapon to penetrate the epithelium and destroy the host extracellular matrix (ECM) component. Before adherence cells, trophozoites secrete immune modulators which stimulate epithelial cells to produce proinflammatory cytokine macrophage migration inhibitory factor (EhMIF). EhMIF induces inflammation resulting in increased production of matrix metalloproteinase (MMP) ${ }^{(13)}$. In a current study, MMP was shown to be needed for the invasion of E. histolytica tissue. MMP rupture the extracellular matrix in the intestine to increase cell migration and is shown excessively in parasitic infections, such as amebiasis ${ }^{(4,13)}$.

\section{Phagocytosis}

Calcium-binding protein 1 (EhCaBP1) and EhC2PK on the ligand are one of the early signs of phagocytosis. EhC2PK binds PS amoeba and attracts EhCaBP1 to cell membranes. EhCaBP1 binds to F-actin which affects cell proliferation, fluid phase endocytosis, and phagocytosis. EhCaBP1 also attracts EhAK1 alpha kinase to phosphorylate directly G-actin. The interaction depends on calcium, while the interactions of EhC2PK and EhCaBP1 are not calcium dependent. Other calcium binding proteins such as EhCaBP3 interact directly with lipids and function in the initiation of independent phagocytosis from the EhCaBP1/EhC2PK pathway. Whereas EhCaBP5, has recently been shown to interact with myosin $1 \mathrm{~B}$ in an independent manner of calcium ${ }^{(11,12)}$.

\section{Trogositosis}

After attaching to the host cell, E. histolytica trophozoite digests host cells with different "bites" called trogocytosis amoeba (Figure 3), which begins to occur within one minute of contact with the host cell. Host cells are still alive when the process starts, but eventually die which is characterized by loss of membrane integrity. After the host cell is killed, the consumption of the amoeba stops and the trophozoite is released from the dead host cell. Trogocytosis of amoeba involve 
physiological temperature, amoeba actin rearrangement, Gal / GalNAc lectin, EhC2PK, and signaling-PI3K. Each protein has a role in phagocytosis and trogocytosis of E. histolytica (Figure 4). Cell death after amoeba trogocytosis can be caused by accumulated physical damage to bitten cells ${ }^{(11)}$.

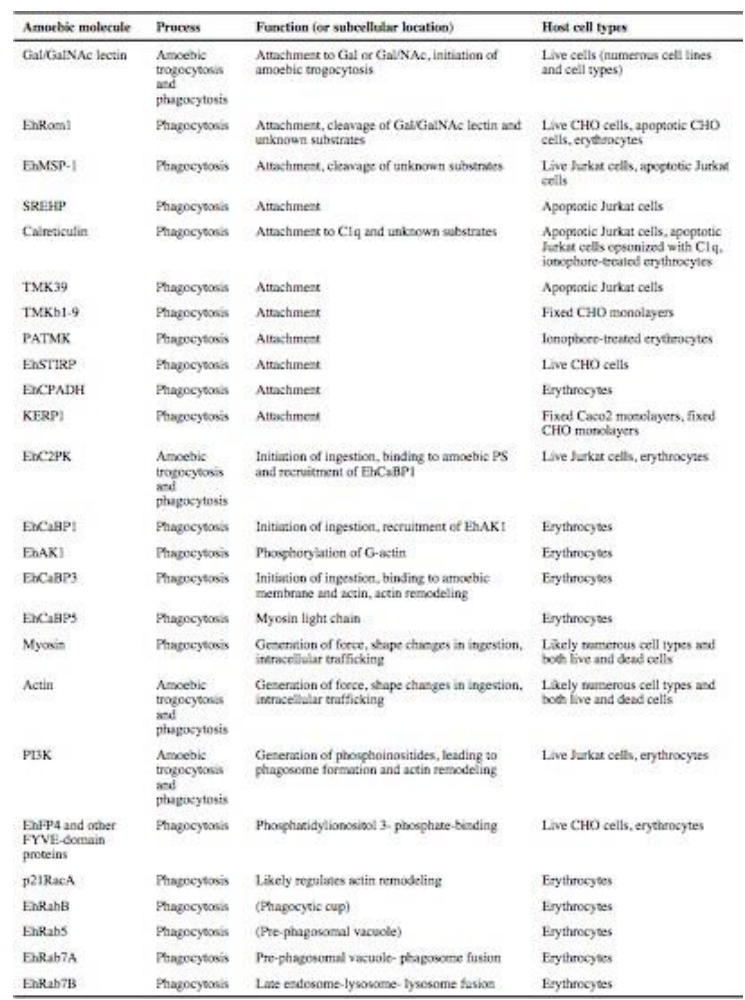

Figure 3. Trogocytosis and Phagocytosis of Amebiasis ${ }^{(11)}$

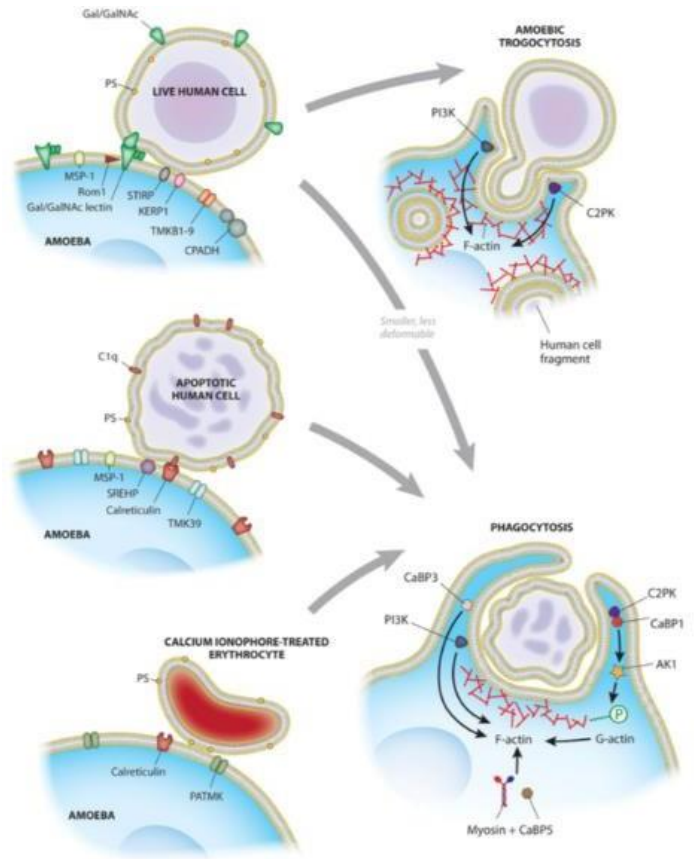

Figure 4. Amoeba molecules that play a role in trogocytosis and phagocytosis ${ }^{(11)}$

\section{IMUN RESPONSE}

E. histolytica has promoted several mechanisms to avoid immune responses and persist in hosts (Figures $5 \& 6$ ). When the amebic trophozoites attack the colon epithelium, it activates an immune response in human hosts. To survive in the host, it is necessary to fight the immune system and control the host environment. The mucous layer in the gastrointestinal tract mostly functions as a major physical barrier to intestinal pathogens. The secondary defense of intestinal immune response to $\mathrm{E}$. histolytica infection is by secreting mucosal immunoglobulins (Ig). One of the most produced Ig by plasma cells is secretory IgA which functions to avoid pathogens from attaching and removing mucosal barriers.

In the early stages of infection, intestinal epithelial cells (IECs) bind and identify the Gal/ Gal NAc lectin via a toll like receptor (TLR), which activates NFKB to produce inflammatory cytokines including IL-6, IL-1 $\beta$, IL-8, IL-12, TNF$\alpha$, and IFN- $\gamma$. IECs are the second defense barrier against pathogens after the mucosal layer and first defense of host cells to fight parasites, host cells secrete an arrangement of pathogen recognition receptors (PRRs), including TLRs. IFN- $\gamma$ is involved in cleaning the infection, whereas IL-4 and TNF- $\alpha$ are associated with disease ${ }^{(13)}$.

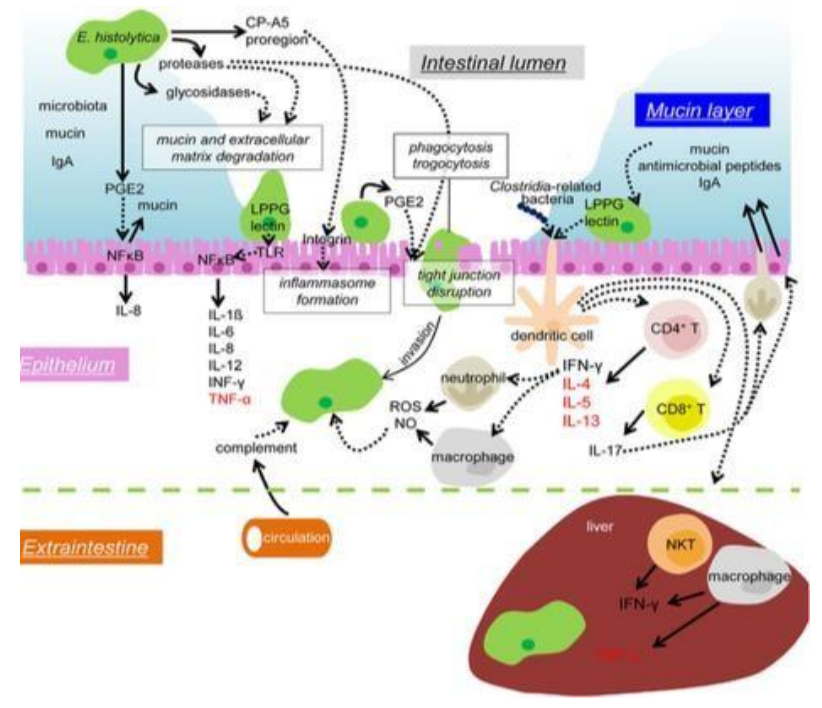


Figure 5. Mechanism of colonization and invasion by E. histolytica trophozoites. ${ }^{(13)}$

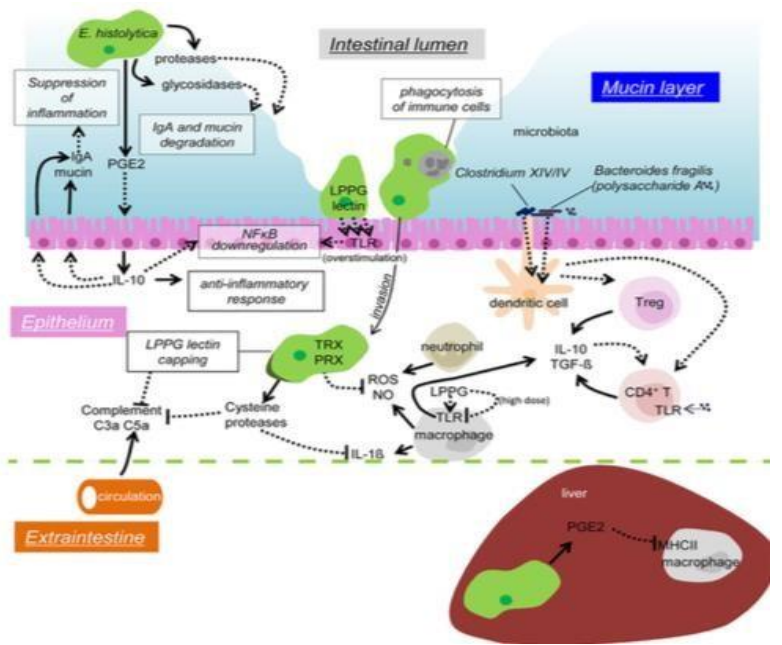

Figure 6. Mechanism of Avoiding Immune Response (13)

\section{THERAPY}

Patients diagnosed with amebiasis should be given medication. Patients with clinical symptoms should take treatment with 2 drugs: amebicidal tissue active agent, metronidazole or tinidazole and luminal cysticidal agent, paromomycin. Patients with asymptomatic amebiasis have need to be given luminal cysticidal agents to avoid invasion and transmission of pathogens ${ }^{(4)}$.

\section{CONCLUSION}

The pathogenesis of amebiasis involves the interaction of several molecules secreted by $\mathrm{E}$. histolytica such as lectin, LPPG, moebapore and cysteine proteases. Advances in molecular methodologies over the past few years have increased understanding of the mechanisms of amebiasis molecular pathogenesis such as adherence, phagocytosis and host cell tropogocytosis. Likewise the mechanism for avoiding cell immune responses such as IL-10 induction and suppression of INF- $\gamma$, reduction of Ig, pro inflammatory cytokines, and complement.

\section{REFERENCES}

1. Farfar J. Manson' s Tropical Diseases Tw e n t y - T h i r d Ed i t i o n. 2013.

2. Nowak P. Entamoeba histolytica - Pathogenic Protozoan of the Large Intestine in Humans. J Clin Microbiol Biochem Technol [Internet]. 2015;1(1):010-7. Available from: https://www.peertechz.com/Clinical-

Microbiology-BiochemicalTechnology/JCMBT-1-103.php

3. Huston CD, Sateriale A. A sequential model of host cell killing and phagocytosis by entamoeba histolytica. J Parasitol Res. 2011;2011.

4. Shirley DAT, Farr L, Watanabe K, Moonah S. A review of the global burden, new diagnostics, and current Therapeutics for amebiasis. Open Forum Infect Dis. 2018;5(7):1-9.

5. Longo DL, Fauci AS. Harrison's Gastroenterology and Hepatology. McGrawHill; 2010.

6. Diarrhoeal disease [Internet]. World Health Organization. 2017 [cited 2018 Oct 30]. Available from: http://www.who.int/newsroom/fact-sheets/detail/diarrhoeal-disease

7. Indonesia DKR. Profil Kesehatan Indonesia. 2009;

8. Mathew G, Bhimji SS. Amebiasis. StatPearls Publ LLC [Internet]. 2018;(August 8, 2018). Available from: https://www.ncbi.nlm.nih.gov/books/NBK5195 35/\#_NBK519535_pubdet_

9. Anorital, Andayasari L. Kajian epidemiologi penyakit infeksi saluran pencernaan yang disebabkan oleh amuba di Indonesia. Media Litbang Kesehat. 2011;21:1-9.

10. Swaminathan A, Torresi J, Schlagenhauf $P$, Thursky K, Wilder-Smith A, Connor BA, et al. A global study of pathogens and host risk factors associated with infectious gastrointestinal disease in returned international travellers. $\mathbf{J}$ Infect [Internet]. 2009;59(1):19-27. Available from: http://dx.doi.org/10.1016/j.jinf.2009.05.008

11. Ralston KS. Chew on this: Amoebic trogocytosis and host cell killing by Entamoeba histolytica. Trends Parasitol. 2016;31(9):442-52.

12. Saha A, Gaurav AK, Bhattacharya S, Bhattacharya A. Molecular Basis of Pathogenesis in Amoebiasis. 2015;143-54.

13. Nakada-Tsukui K, Nozaki T. Immune Response of Amebiasis and Immune Evasion by 
Entamoeba histolytica. Front Immunol. 2016;7(May):1-13.

14. Ayed L Ben, Sabbahi S. PART THREE. SPECIFIC EXCRETED PATHOGENS: ENVIRONMENTAL AND EPIDEMIOLO-GY ASPECTS: ENTAMOEBA HISTOLY-TICA. Glob Water Pathog Proj [Internet]. 2017;(January 15, 2015). Available from: http://www.waterpathogens.org

15. Parasites - Amebiasis - Entamoeba histolytica Infection [Internet]. Centers for Disease Control and Prevention. 2015. Available from: https://www.cdc.gov/parasites/amebiasis/pathog en.html

16. Stanley SL. Amoebiasis. Lancet. 2003;361(9362):1025-34. 